\title{
Respon Guru Terhadap Flip Book Pembelajaran Bioteknologi Berbasis Fermentasi Khas Kalimantan Barat di SMA Kubu Raya
}

\author{
Hanum Mukti Rahayu ${ }^{1 *}$, Mutia Ulyanti' ${ }^{2}$, Mahwar Qurbaniah ${ }^{3}$ \\ ${ }^{1,2,3}$ Program Studi Pendidikan Biologi, Universitas Muhammadyah, Pontianak, Indonesia
}

Pengiriman: 27 Mei 2019; Diterima: 25 Oktober 2019; Publikasi: Oktober 2019

\begin{abstract}
The learning process of biotechnology material in SMA and MA Kubu Raya still has problems such as the lack of learning media that only textbooks and LKS. The textbooks and LKS have drawbacks, including only showing a few images, too much writing and material that does not yet contain the potential of local West Kalimantan biotechnology. So that development is carried out, namely the flip book that has gone through a validation process. However, the untrue response to the flip book is unknown, so the purpose of this study was to determine the teacher's response to the West Kalimantan-based biotechnology flip book learning typical of the Kubu Raya High School. The method used is descriptive with quantitative and qualitative approaches. The data collection tool in this study was using a closed questionnaire. Determination of the sample using purposive sampling technique with consideration of the area and school accreditation. The results showed that the average response of teachers of SMA and MA Kubu Raya to flip books in aspects of attraction was $84.99 \%$, material aspects $82.34 \%$, language aspects $84.73 \%$, and media aspects $74.73 \%$. Based on the results of the research conducted, it can be concluded that the teacher's response to the West Kalimantan-based biotechnology flip book learning typical of SMA Kubu Raya has positive criteria based on aspects of interest, material aspects, language aspects and media aspects.
\end{abstract}

Keywords: biotechnology, flip book, SMA and MA kubu raya

\begin{abstract}
ABSTRAK. Proses pembelajaran materi bioteknologi di SMA dan MA Kubu Raya masih memiliki permasalahan seperti kekurangan media ajar yang hanya menggunakan media berupa buku paket dan lembar kerja siswa (LKS). Buku paket dan LKS tersebut memiliki kekurangan antara lain hanya menampilkan sedikit gambar, terlalu banyak tulisan dan materi belum memuat potensi bioteknologi konvensional lokal Kalbar. Sehingga dilakukan pengembangan yaitu flip book yang telah melalui proses validasi. Namun respon giru terhadap flip book tersebut belum diketahui sehingga tujuan penelitian ini adalah untuk mengetahui respon guru terhadap flip book pembelajaran bioteknologi berbasis fermentasi khas Kalimantan Barat di SMA Kubu Raya. Metode yang digunakan adalah deskriptif dengan pendekatan kuantitatif dan kualitatif. Alat pengumpulan data pada penelitian ini ialah dengan menggunakan angket tertutup. Penentuan sampel dengan menggunakan teknik purposive sampling dengan pertimbangan wilayah dan akreditasi sekolah. Hasil penelitian menunjukkan bahwa rata-rata respon guru SMA dan MA Kubu Raya terhadap flip book pada aspek ketertarikan sebesar $84,99 \%$, aspek materi $82,34 \%$, aspek bahasa $84,73 \%$, dan aspek media $74,73 \%$. Berdasarkan hasil penelitian yang telah dilakukan dapat disimpulkan bahwa respon guru terhadap flip book pembelajaran bioteknologi berbasis fermentasi khas Kalimantan Barat di SMA Kubu Raya memiliki kriteria positif berdasarkan aspek ketertarikan, aspek materi, aspek bahasa dan aspek media.
\end{abstract}

Kata Kunci: Bioteknologi, Flip Book, SMA dan MA Kubu Raya

*Penulis Korespondesnsi

Alamat surel: hanumrahayu@unmuhpnk.ac.id 


\section{PENDAHULUAN}

Bioteknologi merupakan penerapan biosains dan teknologi yang menyangkut aplikasi praktis organisme hidup atau komponen sub selulernya. Salah satu bagian dari bioteknologi adalah fermentasi. Menurut Suryani, dkk (2017:13) Fermentasi merupakan suatu proses perubahan kimia pada substrat organik melalui aktivitas enzim yang dihasilkan oleh mikroorganisme. Produk fermentasi khususnya di Kalimantan Barat memiliki keragaman yang tinggi. Hal tersebut terlihat bervariasinya produk fermentasi khas Kalimantan Barat seperti Ale-ale, Budu, Cencalok, sawi Asin, Pekasam ikan, Peda, Rusip, Tapai, Tauco, Pekasam rebung, Tapai benaon, Tempoyak , Tepung singkong, Terasi, Tempe, Tuak dan Arak.

Fermentasi juga merupakan penerapan bioteknologi konvensional yang merupakan salah satu materi ajar di kelas XII IPA. Proses pembelajaran materi bioteknologi di empat sekolah di Kubu Raya, yaitu MAS Al-Mustaqim, SMA Taman Mulia, SMA 1 Sungai Raya dan SMAS Bhayangkari, yang masih memiliki permasalahan seperti kekurangan media ajar yang hanya menggunakan media berupa buku paket dan lks.

Hasil wawancara guru biologi di sekolah tersebut diperoleh informasi bahwa media pembelajaran yang digunakan berupa buku paket dan lks. Buku paket dan LKS tersebut memiliki kekurangan antara lain hanya menampilkan sedikit gambar dan terlalu banyak tulisan dan peneliti mendapat informasi bahwa di sekolah tersebut masih mempunyai kekurangan materi bioteknologi yang konvensional. Hal ini didukung dengan hasil wawancara guru, diketahui bahwa dalam proses pembelajaran masih terdapat kekurangan media pembelajaran. Untuk mengatasi pemasalahan media pembelajaran tersebut, diperlukan suatu media baru yang telah memiliki kriteria kelayakan media salah satunya yang mungkin dapat diterapkan yaitu Flip book.

Flip book merupakan salah satu alternatif untuk memudahkan proses pembelajaran. Berdasarkan hasil penelitian Hayati, dkk (2015:34) menunjukkan bahwa penggunaan media flip book dapat membantu guru dalam melaksanakan proses belajar mengajar. Agar suatu media dapat digunakan, komponen yang harus ada yakni respon positif guru terhadap media karena tanpa respon dari guru media ini tidak dapat digunakan dalam pembelajaran Namun, sebelum menggunakan media flip book dalam proses pembelajaran harus diketahui terlebih dahulu respon guru terhadap media tersebut.

Respon muncul apabila ada obyek yang diamati ada perhatian terhadap suatu obyek pengamatan dan adanya panca indra sebagai penangkap obyek yang diamati. Dari uraian di atas menunjukkan bahwa respon dapat berupa persyaratan dalam bentuk pendapat yang dianggap baik memenuhi syarat secara rasional dapat dikemukakan sehingga dapat disimpulkan bahwa respon adalah kesan atau reaksi setelah kita mengamati aktivitas mengindra, menilai, obyek terbentuknya sikap terhadap obyek tersebut dapat berupa respon negatif dan positif. Peran media dalam pembelajaran sangat penting yaitu memudahkan guru memfasilitasi pembelajaran. Peran guru dan media harus mampu mengarahkan atau membantu kegiatan proses belajar agar mendapat informasi yang dibutuhkan (Rahmi,2016:111). Itulah sebabnya media flip book sangat penting untuk guru dalam mengatasi pembelajaran tersebut, sehingga memudahkan guru untuk menyampaikan materi yang menurut guru tidak mudah untuk disampaikan saat pembelajaran.

Berdasarkan latar belakang di atas, dikemukan tujuan perumusan masalah bagaimana respon guru terhadap flip book pembelajaran bioteknologi berbasis fermentasi khas Kalimantan di SMA dan MA Kubu Raya.

\section{METODE PENELITIAN}

Metode yang digunakan dalam penelitian ini adalah penelitian deskriptif yang menggambarkan respon guru terhadap flip book produk fermentasi khas kalbar sebagai penunjang pembelajaran bioteknologi di SMA Kubu Raya. Pendekatan yang digunakan dalam penelitian ini adalah pendekatan kualitatif dan kuantitatif. Adapun pengambilan teknik nonprobability sampling yakni dengan teknik purposive sampling. Teknik pengumpulan data menggunakan teknik komunikasi secara langsung dan tidak langsung, observasi, dan dokumentasi. Menggunakan alat pengumpul data Angket, pedoman wawancara dan observasi teknik analisi datauntuk menganalisi data respon guru yang telah terkumpul.langkah-langkah analisi data respon guru dari Masriyah (2006) dalam Indriyani dan Masriyah (2016:4) sebagai berikut :

a. Membuat skor setiap pilihan jawaban dengan menggunakan skala Likert.

b. Menghitung banyak peserta yang memilih setiap pilihan jawaban dari setiap item pertanyaan yang ada.

c. Menghitung skor pada setiap pilihan jawaban sesuai dengan skala Likert.

d. Menghitung total nilai respon peserta setiap item pertanyaan

e. Mencari persentase nilai respons peserta setiap item pertanyaan.

Rumus yang digunakan adalah sebagai 
berikut

$$
\% \mathrm{NRS}=\frac{\sum_{i=1}^{n} \mathrm{NRS}}{\text { NRS Maksimum }} \times 100 \%
$$

Keterangan :

$\%$ NRS : Persentase Nilai Respons Guru (NRS)

$\sum_{i=1}^{n} \mathrm{NRS}$

: Total Nilai Respons Guru (NRS) pada setiap item pertanyaan

NRS maksimum $=\mathrm{n} \times$ skor pilihan terbaik

$$
=\mathrm{n} \times 5 \text {, dengan } \mathrm{n} \text { adalah }
$$$$
\text { banyaknya seluruh responden. }
$$

f. Menginterpretasikan persentase nilai respons peserta didik setiap item pertanyaan dengan menggunakan kategori sebagai berikut :

Tabel 1 Kategori Persentase Respons Guru

\begin{tabular}{lc}
\multicolumn{1}{c}{$\%$ NRS } & Kategori \\
\hline $20 \leq$ NRS $\geq 36$ & Sangat Kurang \\
$36<$ NRS $\geq 52$ & Kurang \\
$52<$ NRS $\geq 68$ & Ragu-Ragu \\
$68<$ NRS $\geq 84$ & Baik \\
$84<$ NRS $\geq 100$ & Sangat Baik
\end{tabular}

g. Menentukan kategori untuk seluruh item pertanyaan, yaitu jika banyaknya kriteria baik dan sangat baik lebih dari atau sama dengan 50\% dari seluruh item pertanyaan, maka respons peserta didik dikatakan positif. Sebaliknya, jika banyaknya kriteria baik dan sangat baik kurang dari 50\% dari seluruh item, maka respons peserta didik dikatakan negatif.

\section{HASIL DAN PEMBAHASAN}

Penelitian ini bertujuan untuk mengetahui respon guru terhadap flip book produk fermentasi khas Kalimantan Barat sebagai penunjang pembelajaran bioteknologi di SMA Kubu Raya. Data angket respon guru diperoleh dari 9 SMA di Kubu Raya yang berjumlah 12 guru terdiri dari 1 guru SMAN 1 Sungai Raya, 1 guru SMAN 2 Sungai Raya, 1 guru SMAN 4 Sungai Raya, 1 guru SMAS Adisucipto, 1 guru SMAS Taman Mulia, 3 guru SMAS Kemala Bhayangkari, 1 guru SMAS Indonesia Muda, 1 guru MA Raudlatul Firdaus, dan 2 guru MAS Al-Mustaqim.

\section{HASIL}

Adapun hasil keseluruhan respon guru SMA dan MA Kubu Raya terhadap flip book dapat dilihat pada Gambar 1.

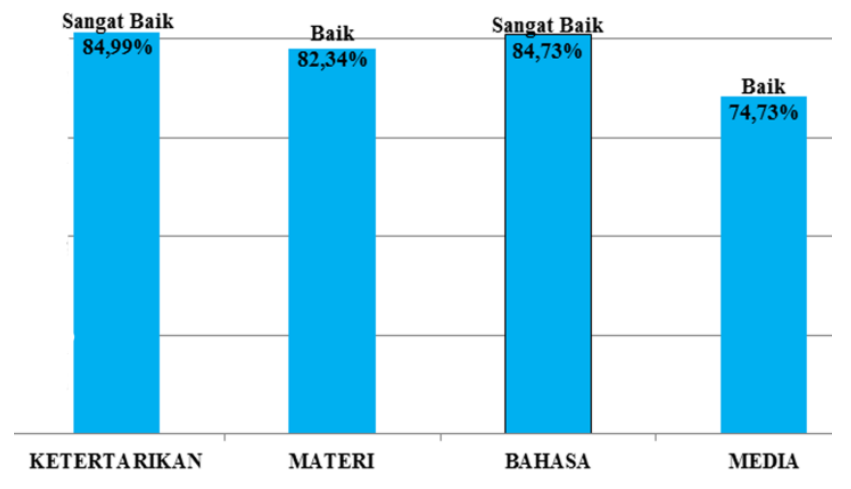

Gambar 1. Hasil keseluruhan respon guru SMA dan MA Kubu Raya terhadap flip book

Menunjukkan bahwa nilai keseluruhan ratarata respon guru SMA Kubu Raya terhadap flip book pada setiap aspek memiliki kriteria baik dan sangat baik, sehingga flip book dapat digunakan dalam proses pembelajaran.

\section{PEMBAHASAN}

Respon merupakan kesan atau reaksi setelah mengamati aktivitas mengindra, menilai obyek terbentuknya sikap terhadap obyek tersebut dapat berupa sikap negatife atau positif ( Nurul Hidayah, dkk, 2013:105 ). Respon muncul apabila ada obyek yang diamati, ada perhatian terhadap suatu obyek pengamatan dan adanya pancaindra sebagai penangkap obyek yang diamati, selain itu dalam pemunculannya respon ada beberapa faktor yang mempengaruhi yaitu pengalaman, proses belajar, tingkat pengalaman dan nilai kepribadianya.

Penelitian ini bertujuan untuk mengetahui respon guru terhadap flip book pembelajaran bioteknologi berbasis fermentasi khas Kalimantan Barat di SMA Kubu Raya. Respon guru yang dimaksud adalah tanggapan dan ketertarikan guru terhadap flip book produk fermentasi khas Kalimantan Barat sebagai penunjang pembelajaran bioteknologi. Data respon guru diambil dari 12 guru SMA dan MA di Kubu Raya.

Hasil analisis data angket respon guru SMA dan MA di Kubu Raya terhadap flip book produk fermentasi khas Kalimantan Barat menunjukkan bahwa persentase dari keempat aspek, yakni aspek ketertarikan, materi, bahasa, dan media berada pada kategori baik dan sangat baik. Hal ini berarti guru memberikan respon positif terhadap flip book produk fermentasi khas Kalimantan Barat. Hal ini sesuai pendapat Wicaksono (2014:547) respon positif diperoleh jika kategori angket respon menunjukkan lebih dari 50\% pernyataan mendapatkan respon baik atau sangat baik, sehingga media dikatakan layak digunakan dalam pembelajaran. 
Hasil penelitian menunjukkan adanya perbedaan respon yang diberikan oleh guru dari setiap sekolah terhadap flip book baik dan sangat baik berdasarkan aspek ketertarikan, aspek materi, aspek bahasa dan aspek media. Perbedaan tersebut dapat disebabkan adanya perbedaan minat guru terhadap penggunaan flip book dan pemahaman pada materi yang diajarkan.

1. Aspek ketertarikan

Respon guru pada aspek ketertarikan menunjukkan bahwa guru tertarik untuk menggunakan flip book produk fermentasi khas Kalimantan Barat sebagai penunjang pembelajaran bioteknologi. Hal ini dibuktikan dengan respon guru terhadap aspek ketertarikan menunjukan sangat baik yakni $84,99 \%$. Berdasarkan hasil wawancara guru dan observasi, diketahui bahwa media yang digunakan guru yaitu LKS. Guru mengatakan LKS dan buku paket yang digunakan selama ini kurang mendukung karena tampilannya tidak berwarna serta memuat banyak tulisan, kertas yang digunakan buram dan sedikit menampilkan gambar, begitu pula dengan buku paket yang hanya memiliki sedikit warna. Oleh karena itu, flip book pembelajaran bioteknologi berbasis fermentasi khas Kalimantan Barat ini didesain semenarik mungkin dengan menggunakan warna-warna yang cerah, dan menampilkan banyak gambar-gambar serta memuat materi mengenai produk fermentasi yang ada di Kalimantan Barat.

Adapun hasil penelitian diketahui bahwa persentase respon terendah yaitu 80,00. Berdasarkan aspek ketertarikan adalah guru dari SMAS Adisucipto dan SMAS Taman Mulia diketahui bahwa guru kurang menyukai pemilihan jenis huruf, ukuran serta spasi karena di setiap tampilan jenis huruf, ukuran dan spasi berbeda-beda. sedangkan, persentase respon tertinggi berdasarkan aspek ketertarikan diberikan oleh guru MAS Al-Mustaqim dan SMAS Indonesia Muda. Hasil wawancara dengan guru Al-Mustaqim dan SMAS Indonesia Muda diketahui bahwa guru menyukai gambar dan warna yang terdapat pada flip book. Penggunaan flip book dapat menambah motivasi belajar peserta didik dan juga dapat mempengaruhi prestasi dan hasil belajar peserta didik, penggunaan flip book juga dapat meningkatkan pemahaman dan meningkatkan pencapaian hasil belajar ( Muladi, 2013:102 ).

2. Aspek Materi

Berdasarkan aspek materi, guru memberikan respon positif terhadap flip book. Hal ini dibuktikan dengan respon guru terhadap aspek media menunjukan respon baik yakni 82,34\%. Materi merupakan komponen terpenting dalam pembelajaran karena berhubungan dengan informasi yang akan disampaikan guru dan dipahami oleh siswa.

Adapun hasil penelitian aspek materi dengan respon terendah yaitu 70,00. Berdasarkan aspek media adalah guru SMAN 2 Sungai Raya diketahui bahwa dalam pembuatan flip book dibagian pembuatan tempe ditambahkan sejumlah bahan yang diperlukan. Hasil wawancara dengan Al-Mustaqim diketahui bahwa materi flip book berkaitan dengan lingkungan sekitar menambahkan pengetahuan guru tentang makanan fermentasi Khas Kalimantan Barat dan juga terdapat saran dari beberapa guru bahwa bagian flip book harus ditambahkan bagian komposisi pada setiap bahan yang ada di flip book.

\section{Aspek Bahasa}

Berdasarkan aspek bahasa, guru memberikan respon positif terhadap flip book. Rata-rata persentase respon guru terhadap aspek bahasa yakni $84,73 \%$. Respon guru terhadap aspek bahasa menunjukkan flip book sudah menggunakan bahasa yang sederhana, mudah dipahami dan sesuai dengan EYD. Penggunakan bahasa yang sederhana dan sesuai dengan EYD akan membuat siswa lebih mudah memahami materi yang termuat di dalam flip book.

Adapun hasil penelitian respon terendah berdasarkan aspek bahasa diberikan oleh guru SMAN 4 sungai raya menyatakan bahwa kurang memahami maksud dari EYD sesuai kaidah Bahasa Indonesia sehingga terdapat pemberian penilian yang sedikit keliru. dan respon tertinggi diberikan guru SMAS Indonesia Muda diketahui flip book telah dibuat dengan bahasa yang sederhana dan memudahkan guru dalam memahami materinya. Berdasarkan penilaian guru di setiap flip book didapatkan catatan sebagai saran perbaikan, yaitu memperbaiki bagian tata bahasa, penulisan tanda baca harus sesuai dengan ejaan bahasa Indonesia.

\section{Aspek Media}

Selanjutnya guru memberikan respon positif pada aspek media yang menunjukkan bahwa flip book telah memiliki kegrafikan yang layak digunakan dalam pembelajaran. Respon guru terhadap aspek media memiliki nilai rata-rata $74,73 \%$.

Adapun hasi penelitian respon guru terendah pada aspek pada aspek media diberikan oleh guru SMAN 2 Sungai Raya diketahui bahwa guru SMAN 2 Sungai Raya gambar pada flip book masih sedikit memuat jenis makanan Khas Kalimantan Barat sedangkan respon tertinggi diberikan oleh guru MA Raudlatul Firdaus menjelaskan bahwa aspek media berkaitan dengan gambar yang memudahkan guru dalam mengetahui jenis makanan Khas Kalimantan Barat. 
Media pembelajaran merupakan alat penyampaian informasi dari guru kepada peserta didik. Mahnum (2012:27) menjelaskan bahwa media pembelajaran merupakan wadah dan penyalur pesan dari sumber pesan, dalam hal ini guru kepada penerima pesan dalam hal ini peserta didik. Flip book produk fermentasi khas Kalimantan Barat yang telah dikembangkan menampilkan gambar dan ilustrasi sehingga dapat meningkatkan pemahaman peserta didik. Utariyanti dkk (2015:350) menjelaskan dengan adanya gambar dan penjelasan pada gambar, peserta didik akan memiliki gambaran tentang apa yang akan dipelajari di setiap topiknya. Kemudian, Alkhalim (2013:3) juga menjelaskan bahwa gambar yang ditampilkan mendekati kenyataan atau sesuai subjek akan membuat materi yang disampaikan dapat dengan mudah dimengerti dan hasil yang diterima peserta didik akan sama.

Berdasarkan hasil penelitian diketahui bahwa persentase respon terendah dari kesembilan sekolah berdasarkan empat aspek ketertarikan, materi, bahasa dan media ialah guru dari SMAN 2 Sungai Raya dan SMAN 4 Sungai Raya pada aspek materi, bahasa dan media. Berdasarkan hasil wawancara dengan guru SMAN 2 Sungai Raya dan SMAN 4 Sungai Raya bahwa penulisan nama latin pada flip book harus dipisah dari nama daerah dan cara pembuatan bagusnya dibuat penomoran. Sedangkan, persentase respon tertinggi berdasarkan aspek ketertarikan diberikan oleh guru MAS Al- Mustaqim dan SMAS Indonesia Muda diketahui bahwa guru menyukai gambar dan warna yang terdapat pada flip book. Kemudian respon tertinggi berdasarkan aspek materi, bahasa, dan media diberikan oleh guru MAS AlMustaqim, SMAS Indonesia Muda dan MA Raudlatul Firdaus. Hasil wawancara dengan guru MAS Al-mustaqim, SMAS Indonesia Muda dan MA Raudlatul Firdaus diketahui bahwa materi flip book yang berkaitan dengan lingkungan sekitar menambahkan pengetahuan guru tentang makanan fermentasi khas Kalimantan Barat, penggunaan bahasa yang sederhana memudahkan guru dalam memahami isi materinya dan penggunaan media yang sebagai alat penyampaian informasi dari guru kepada perserta didik.

Adapun tambahan penilaian guru bagian flip book penulisan dirapikan, penempatan tata letak kurang sesuai ( terlalu penuh ), bagian gambar harus diberi nama, bagian indikator harus diperbaiki, komposisi ditambah lagi, deskripsinya dilengkapi lebih baik lagi.

\section{KESIMPULAN DAN SARAN}

Berdasarkan hasil penelitian yang telah dilakukan dapat disimpulkan bahwa respon guru terhadap flip book pembelajaran bioteknologi berbasis fermentasi khas Kalimantan Barat di SMA Kubu Raya memiliki kriteria positif berdasarkan aspek ketertarikan, aspek materi, aspek bahasa dan aspek media.

\section{DAFTAR PUSTAKA}

Alvitri Wijayanti, dkk. (2015). Respon Petani Terhadap Inovasi Budi daya dan pemanfaat sorgum dikecamatan srandakan kabupaten Bantul. Jurnal Argo Ekonomi. 26(2).

Nurhidayati, S., \& Khaeruman. (2017). Pengembangan Bahan Ajar Bioteknologi Berbasis Potensi Lokal. Jurnal Jupe. 2(2) 87-91.

Putra, B.F., Ardi., \& Leilani, I. (2017). Pengembangan Media Pembelajaran Interaktif menggunakan Aplikasi Flash Flip Book tentang Materi Animalia untuk Peserta Didik Kelas X SMAN 1 Pariaman. Journal Biosains. 1(2): 165-173.

Ramdayana, (2014). Media Pembelajaran Dengan Menggunakan Media flip book (Kvisoft flip book Maker Pro) Sub Materi Atmosfer. Samarinda : Universitas Mulawarman.

Rafikayuni.,dkk. (2017). Respon siswa terhadap lks berbasis predict Observe explanation (poe) pada submateri Keanekaragaman hayati kelas X. Fakultas Pendidikan MIPA dan Teknologi IKIP PGRI Pontianak: 343.

Sugiyono. (2014). Metode Penelitian Kuantitatif Kualitatif dan $R \& D$. Bandung: Alfabeta.

Wicaksono, D.P., dkk. (2014). Pengembangan Perangkat Pembelajaran Matematika Berbahasa Inggris berdasarkan Teori Kecerdasan Majemuk (Multiple Intelligences) pada Materi Balok dan Kubus untuk Kelas VIII SMP. Jurnal Elektronik Pembelajaran Matematika. 2(5): 534-549.

Yulistiani, dkk. (2014). Evaluasi Proses Fermentasi Pada Kualitas Tempoyak. Jurnal Rekapangan. 8(1): 84.

Yani suryani, dkk. (2017). Pengaruh penambahan urea dan sulfur pada limbah padat bioetanol yang difermentasikan em-4 terhadap kandungan protein dan serat kasar. Jurnal ilmiah peternakan terpadu. 5 (1):13.

Zainal, B., dkk. (2016). Pengaruh Kuantitas Garam Terhadap Kualitas Bekasam. Jurnal Biota. 2(2): 154. 